\title{
LIMBAH INDUSTRI FILET IKAN PATIN UNTUK HIDROLISAT PROTEIN
}

\author{
Mala Nurilmala*, Tati Nurhayati, Rieska Roskananda \\ Departemen Teknologi Hasil Perairan, Fakultas Perikanan dan Ilmu Kelautan, IPB \\ Jalan. Lingkar Akademik, Kampus IPB Dramaga-Bogor 16680 \\ Telepon. +622518622915 Faks. +622518622916. \\ ${ }^{*}$ Korespondensi : mnurilmala@ipb.ac.id \\ Diterima: 10 Februari 2018/ Disetujui: 11 Juli 2018
}

Cara sitasi: Nurilmala M, Nurhayati T, Roskananda R. 2018. Limbah industri filet ikan patin untuk hidrolisat protein. Jurnal Pengolahan Hasil Perikanan Indonesia. 21(2): 287-294.

\begin{abstract}
Abstrak
Limbah industri filet ikan patin terutama kepala dan tulang memiliki potensi sebagai bahan baku pembuatan hidrolisat protein. Hidrolisat protein merupakan hasil hidrolisis protein dan diketahui memiliki manfaat bioaktif. Tujuan penelitian ini untuk membuat hidrolisat protein dari limbah industri filet ikan patin dan menentukan aktivitas pengikatan kalsiumnya. Penelitian ini terdiri dari dua tahap, tahap pertama terdiri dari pembuatan hidrolisat protein secara enzimatis menggunakan konsentrasi enzim papain yang berbeda (4\%, 5\% dan 6\%). Hidrolisat protein tersebut dianalisis derajat hidrolisisnya dan aktivitas pengikatan kalsium dengan menggunakan AAS. Tahap kedua yaitu analisis UV scanning untuk melihat penyerapan maksimum hidrolisat protein dan analisis komposisi asam amino. Derajat hidrolisis yang dihasilkan dari penelitian ini berbanding lurus dengan konsentrasi enzim yang digunakan. Hidrolisat protein tersebut memiliki derajat hidrolisis 43,13\% pada konsentrasi enzim 6\% (v/v). Aktivitas pengikatan kalsium tertinggi oleh hidrolisat protein yaitu $122,73 \mathrm{mg} \mathrm{L}-1$. Intensitas serapan pada hidrolisat protein dengan penambahan kalsium lebih rendah apabila dibandingkan dengan intensitas absorpsi hidrolisat protein tanpa penambahan kalsium, hal ini mengindikasikan adanya aktivitas pengikatan kalsium oleh hidrolisat protein. Komposisi asam amino tertinggi pada hidrolisat protein limbah filet ikan patin yaitu asam glutamat.
\end{abstract}

Kata kunci: hidrolisat protein, kalsium, limbah filet patin, Pangasius pangasius, papain

\section{Waste of Patin Filleting Industry for Protein Hydrolysate}

\begin{abstract}
Patin (Pangasius) filleting industry by-products, particularly head and bone are potential sources for protein hydrolysate. Protein hydrolysate are hydrolysis products of proteins and are known to have various bioactive functions. Thus, the aims of this research were to produce protein hydrolysate as well as to determine its calcium binding activity. This research was conducted into two steps. The first step was to produce the protein hydrolysate using papain with the concentrations of $4 \%, 6 \%$ and $8 \%(v / v)$. Subsequently, degree of hydrolysis and calcium binding of the protein hydrolysate were determined. The second steps was to investigate the maximum absorption of protein hydrolysate and its amino acid analysis. The result showed that the degree of hydrolysis of the protein hydrolysate was increased with the increasing concentration of papain. The degree of hydrolysis was $43.13 \%$ by Papain $6 \%(\mathrm{v} / \mathrm{v})$. Meanwhile the highest calcium-binding activity of the protein hydrolysate was $122.73 \mathrm{mg} \mathrm{L}^{-1}$. The absorption intensity of protein hydrolysate with the addition of calcium was lower compared than that of without addition of calcium, indicating the calcium was effectively bound by protein hydrolysate. The highest content of amino acid of fish protein hydrolysate was glutamic acid.
\end{abstract}

Keywords: calcium-binding, catfish fillet by product, Pangasius pangasius, papain, protein hydrolysate 


\section{PENDAHULUAN}

Indonesia merupakan negara yang memiliki potensi produksi perikanan yang tinggi. Sumbangsih perikanan Indonesia tidak dapat dipisahkan dari perikanan budidaya, yang tumbuh secara signifikan dari tahun ke tahun. Produksi ikan patin dari tahun 2010 hingga tahun 2014 menunjukan pola yang selalu meningkat yaitu sebesar 147.888 ton pada tahun 2010 menjadi 418.002 ton pada tahun 2014 (KKP 2015). Perbandingan total produksi ikan patin nasional terhadap total produksi ikan patin dunia pada tahun 2011 bahkan menempatkan Indonesia menempati urutan kedua terbesar sebagai penghasil produk patin (KKP 2013).

Proses pengolahan ikan di Indonesia menghasilkan produk filet yang kemudian dijual dalam bentuk filet segar maupun beku (Hastarini et al. 2012). Sathivel et al. (2012) menyebutkan bahwa rendemen pada proses pengolahan filet ikan patin hanya sekitar $45 \%$ sehingga menghasilkan presentase limbah yang cukup besar.

Limbah dari hasil pengolahan ikan patin telah menimbulkan permasalahan baru, oleh karena itu, pemanfaatan dan pengolahan limbah dari kegiatan filet ikan patin diperlukan agar dapat mengurangi dampak negatif dari limbah yang dihasilkan oleh industri pengolahan filet patin. Utomo et al. (2014) menjelaskan bahwa limbah filet ikan patin dapat diolah menjadi hidrolisat protein sehingga mempunyai nilai ekonomis.

Hidrolisat protein ikan (HPI) merupakan produk cair yang terbuat dari ikan dengan penambahan enzim proteolitik untuk mempercepat proses hidrolisis dalam kondisi yang terkendali dengan hasil akhir berupa campuran komponen protein (Piggot dan Tucker 1990). Hidrolisat protein ikan dapat digunakan sebagai suplemen makanan atau dapat dimakan langsung sebagai makanan untuk meningkatkan asupan protein (Utomo et al. 2014). Chalamaiah et al. (2012) menjelaskan bahwa hidrolisat protein ikan dari reaksi pemecahan enzimatis dapat mengkonversi protein ikan menjadi peptida yang lebih kecil yang biasanya mengandung 2-20 asam amino.
Nie et al. (2014) menjelaskan bahwa hidrolisat protein tersusun atas bioaktif peptida yang memiliki aktivitas pengikatan kalsium. Aktivitas pengikatan kalsium berfungsi untuk memaksimalkan penyerapan kalsium dalam tubuh. Charoenphun et al. (2013) menjelaskan bahwa perubahan $\mathrm{pH}$ akibat eksresi asam lambung akan mengakibatkan kurangnya kelarutan kalsium dalam tubuh sehingga asupan kalsium menjadi kurang optimal. Mardiyah dan Sartika (2014) menjelaskan bahwa asupan kalsium yang optimal diperlukan untuk memaksimalkan massa puncak serta mempertahankan massa tulang pada usia dewasa serta meminimalkan kehilangan massa tulang pada usia lebih lanjut. Sharma et al. (2011) menyebutkan bahwa asam amino mempunyai sifat yang anionik sehingga memungkinkan dalam pembentukan kompleks yang larut dengan kalsium dan mencegah pembentukan kalsium fosfat yang tidak larut.

Limbah filet ikan patin terutama kepala dan tulang dalam bentuk hidrolisat protein diduga mempunyai potensi dalam aktivitas pengikatan kalsium sehingga diharapkan menjadi alternatif baru untuk konsumen yang cenderung intoleran terhadap laktosa.

\section{BAHAN DAN METODE Bahan dan Alat}

Bahan yang digunakan dalam penelitian ini adalah limbah filet patin berupa kepala dan tulang dari Unit produksi Hasil Perairan, Departemen Teknologi Hasil Perairan, Fakultas Perikanan dan Ilmu Kelautan, Institut Pertanian Bogor dan enzim papain (Merck. Jerman) dengan aktivitas 40 USP. Bahan lainnya yang digunakan untuk analisis derajat hidrolisis adalah trichloroacetic acid (Merck, Jerman). Bahan untuk analisis asam amino yaitu $\mathrm{HCl}$, larutan buffer kalium borat $\mathrm{pH}$ 10,4; peraksi ortoftaladehida (OPA), Naasetat, Na-EDTA, methanol, tetrahidrofuran (THF), larutan brij-30, larutan standar amino $0,5 \mu \mathrm{mol} / \mathrm{mL}$. Bahan untuk analisis pengikatan kalsium $\mathrm{CaCl}_{2}$ dan $\mathrm{NaOH}$. Bahan kimia yang digunakan berasal dari produsen Merck, Jerman. 
Alat yang digunakan pada penelitian ini meliputi alat untuk preparasi, timbangan digital (Oxone), blender, centrifuge (HIMAC CR 21G), waterbath shaker (Wise bath shaker WSB-18), freeze dryer (Chris Alpha 2-43360 harz), kertas saring whatman no 1, tanur pengabuan, High Performance Liquid Chromatography (HPLC) (Shidmadzu), Atomic Absorption Spektrofotometer (AAS) (Shidmadzu), desikator dan vortex.

\section{Metode Penelitian \\ Pembuatan hidrolisat protein}

Pembuatan hidrolisat protein menggunakan metode hidrolisis enzimatis mengacu Utomo et al. (2014). Limbah filet ikan patin yang berupa tulang dan kepala dihaluskan kemudian dicampur akuades dengan rasio 1:7 (Charoenphun et al. 2013). Campuran kemudian diblender dan dihomogenisasi. Homogenat disesuaikan pada pH 8 . Homogenat dihidrolisis dengan penambahan enzim papain konsentrasi 4\%, 6\% dan $8 \%$ (v/v) selama 5 jam pada suhu $55^{\circ} \mathrm{C}$. Selanjutnya, hidrolisat dipanaskan dengan suhu $80^{\circ} \mathrm{C}$ selama 20 menit dengan tujuan untuk menginaktivasi enzim. Sampel kemudian disentrifugasi selama 20 menit pada $5000 \mathrm{xg}$ bertujuan memisahkan supernatan dan natan. Hidrolisat protein berupa supernatan kemudian dianalisis lebih lanjut.

\section{Pengukuran derajat hidrolisis}

Perhitungan derajat hidrolisis mengacu penelitian Amiza et al. (2012). Sebanyak 20 $\mathrm{mL}$ hidrolisat protein ditambahkan TCA $20 \% \quad(\mathrm{~b} / \mathrm{v})$ sebanyak $20 \mathrm{~mL}$. Campuran kemudian didiamkan selama 30 menit agar terjadi pengendapan, kemudian disentrifugasi (kecepatan $7.800 \mathrm{xg}$, selama 15 menit). Supernatan dianalisis kadar nitrogennya menggunakan metode Kjeldahl (AOAC 2005). Derajat hidrolisis dihitung menggunakan rumus berikut (Hoyle dan Merritt, 1994):

Derajat hidrolisis $=\frac{\text { Nitrogen terlatut TCA } 10 \%}{\text { Nitrogen total sampel }} \times 100 \%$

\section{Analisis kapasitas pengikatan kalsium menggunakan AAS}

Pengujian aktivitas pengikatan kalsium mengacu pada metode Mendez et al. (2013) dengan modifikasi. Sampel hidrolisat protein sebanyak $4 \mathrm{~mm}$ dicampur dengan $1 \mathrm{~mL} \mathrm{CaCl}$ $0,006 \mathrm{~N}$, selanjutnya campuran didiamkan selama 30 menit pada suhu $30^{\circ} \mathrm{C}$ dengan $\mathrm{pH}$ 7,8. Sampel disaring menggunakan kertas Whatman no.1.

Kandungan kalsium filtrat diuji dengan AAS. Konsentrasi enzim terbaik yang memiliki aktivitas pengikatan kalsium tertinggi dalam pembuatan HPI diuji lanjut menggunakan $U V$-scanning dan dilakukan analisis asam amino

\section{Analisis UV-Scanning}

Analisis UV-scanning mengacu pada metode Nie et al. (2014). Daerah serapan yang digunakan pada penelitian ini antara 200-400 nm. Sampel hidrolisat protein sebanyak $4 \mathrm{~mL}$ dicampur dengan $1 \mathrm{~mL} \mathrm{CaCl}$ 0,006 N. Campuran didiamkan selama 30 menit pada suhu $30^{\circ} \mathrm{C}$ dengan $\mathrm{pH} 7,8$. Sampel disaring menggunakan kertas Whatman no.1 kemudian dilakukan UV-scanning pada panjang gelombang 200-400 nm. Tujuan analisis UV-scanning pada penelitian ini yaitu untuk menentukan puncak serapan pada hidrolisat protein dan hidrolisat protein dengan penambahan $\mathrm{CaCl}_{2}$.

\section{Analisis asam amino}

Analisis asam amino dilakukan untuk mengetahui karakteristik asam amino yang terdapat pada produk. Prinsip analisis asam amino menggunakan HPLC adalah memanfaatkan reaksi pra kolom gugus amino, yaitu pereaksi ortoftalaldehida (OPA) yang akan bereaksi dengan asam amino primer. Asam amino primer dalam suasana basa, mengandung merkaptoetanol membentuk senyawa yang berfluorensensi sehingga dapat dideteksi dengan detektor fluoresensi. Analisis asam amino dilakukan menggunakan metode AOAC (2005). 


\section{HASIL DAN PEMBAHASAN Derajat Hidrolisis}

Derajat hidrolisis merupakan parameter kunci dalam memantau reaksi hidrolisis, semakin tinggi derajat hidrolisis menunjukkan semakin efektif proses hidrolisis dalam memecah ikatan peptida (Charoenphun et al. 2013). Nilai rata-rata derajat hidrolisis hidrolisat protein limbah filet ikan patin dengan konsentrasi enzim yang berbeda disajikan pada Gambar 1.

Data pada Gambar 1 menunjukkan perbedaan nilai derajat hidrolisis yang signifikan pada masing-masing konsentrasi enzim papain yang digunakan. Derajat hidrolisis hidrolisat protein dengan konsentrasi enzim papain 8\% (v/v) lebih tinggi dibandingkan derajat hidrolisis hidrolisat protein dengan konsentrasi enzim papain $4 \%$ dan $6 \% \quad(\mathrm{v} / \mathrm{v})$. Nurhayati et al. (2013) menyatakan bahwa semakin besar konsentrasi enzim papain yang ditambahkan akan menyebabkan peningkatan nilai derajat hidrolisis yang dihasilkan. Haslaniza et al. (2010) menjelaskan bahwa semakin tinggi konsentrasi enzim yang digunakan akan menyebabkan peningkatan nitrogen terlarut dalam hidrolisat protein akibat terjadinya pemutusan ikan peptida. Kondisi ini menyebabkan terjadinya peningkatan nilai derajat hidrolisis.

\section{Kapasitas Pengikatan Kalsium Hidrolisat Protein}

Hidrolisat protein limbah ikan patin memiliki aktivitas pengikatan kalsium yang berbeda pada setiap kosentrasi enzim papain. Nilai rata-rata aktivitas pengikatan kalsium dari masing-masing perlakuan disajikan pada Gambar 2.

Hidrolisat protein dengan konsetrasi ezim papain $4 \%$ menghasilkan aktivitas pengikatan kalsium sebesar 22,75 mg/L, lebih rendah apabila dibandingkan dengan aktivitas pengikatan kalsium untuk hidrolisat protein dengan konsentrasi enzim papain 6\% yaitu $122,73 \mathrm{mg} / \mathrm{L}$ dan hidrolisat konsentrasi $8 \%$ yaitu 57,48 mg/L. Gambar 2 menunjukkan perbedaan kapasitas pengikatan kalsium yang signifikan pada masing-masing konsentrasi enzim papain yang digunakan. Kapasitas pengikatan kalsium mengalami kenaikan pada konsentrasi enzim papain $6 \%(\mathrm{v} / \mathrm{v})$ akan tetapi menurun pada konsentrasi enzim papain 8\% (v/v). Thuy et al. (2015) melaporkan bahwa sifat fungsional pada hidrolisat protein seperti aktivitas pengikatan kalsium yang maksimal tidak tercapai pada derajat hidrolisis yang paling tinggi. Hal tersebut dikarenakan semakin tinggi nilai derajat hidrolisis yang dihasilkan akan menyebabkan ukuran molekul protein yang semakin kecil. Charoenphun et al. (2013) menyatakan

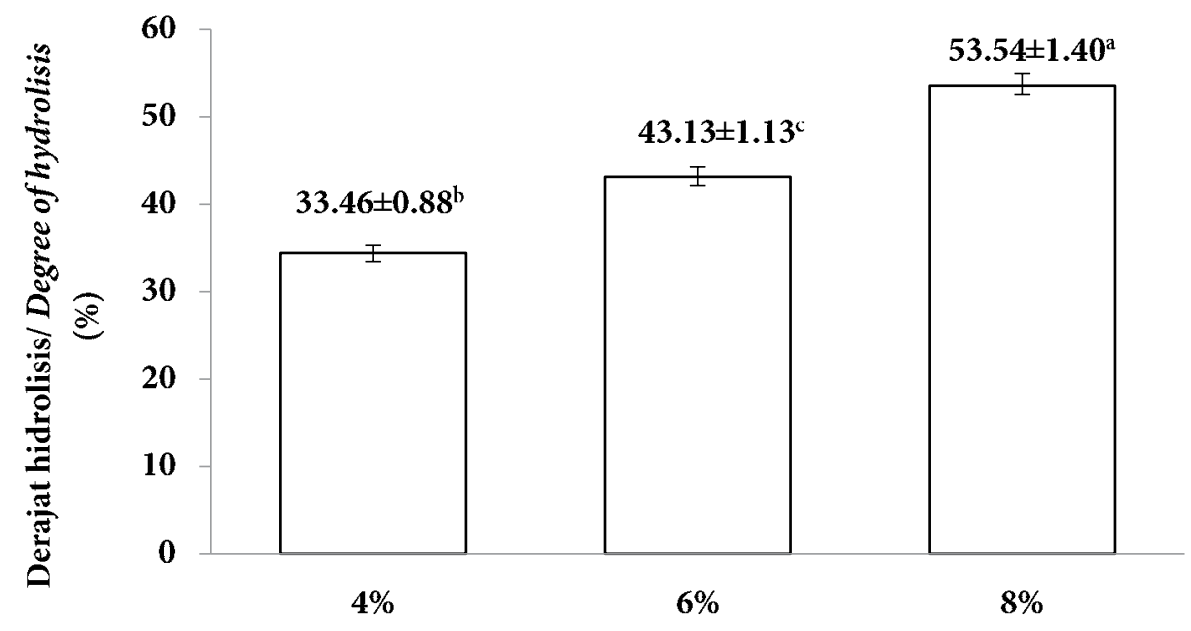

Konsentrasi papain/Papain concentration

Gambar1 Nilai derajat hidrolisis hidrolisat protein limbah filet ikan patin dengan konsentrasi yang berbeda

Figure 1 Hydrolysis of hydrolyzate grades of patin (Pangasius pangasius) fillet waste protein with different concentrations 


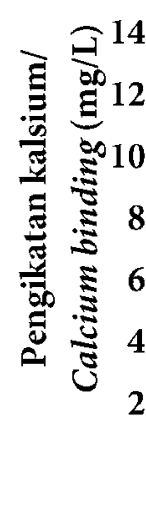

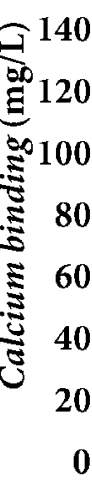

(1)
$22.75 \pm 1.09^{b}$

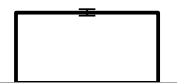

4
$122.73 \pm 8.17^{\mathrm{a}}$

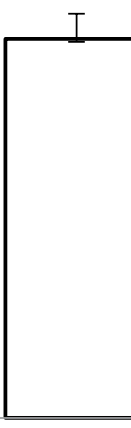

6
$57.48 \pm 6.45^{\circ}$

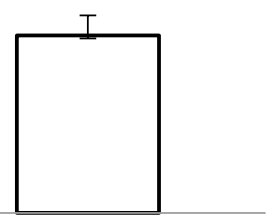

8

Konsentrasi papain / Papain concentration (\%)

Gambar 2 Kapasitas pengikatan kalsium hidrolisat protein pada konsentrasi enzim yang berbeda Figure 2 Capacity of binding of calcium hydrolyzate protein with different enzyme concentrations

bahwa berat molekul pada hidrolisat protein ikan nila memainkan peranan yang cukup penting dalam aktivitas pengikatan kalsium. Hoa et al. (2008) menyebutkan peptida dengan panjang asam amino sekitar 7-30 umumnya mempunyai kemampuan pengikatan kalsium paling optimal.

\section{Hasil UV-Scanning dari Hidrolisat Protein}

Daerah serapan yang digunakan pada penelitian ini antara $200-400 \mathrm{~nm}$. Tujuan analisis UV-scanning pada penelitian ini yaitu untuk menentukan puncak serapan pada hidrolisat protein dan hidrolisat protein dengan penambahan $\mathrm{CaCl}_{2}$.

Koefisien penyerapan maksimum protein merupakan perwakilan dari stuktur khas protein (Goldfarb et al. 1951). Protein biasanya menunjukkan penyerapan maksimum antara 275-280 nm, hal tersebut disebabkan oleh absorbansi dari asam amino aromatik (Schmid 2001). Absorbansi maksimum pada hidrolisat protein limbah filet ikan patin (Gambar 5) terjadi antara panjang gelombang 275-285 nm. Penambahan $\mathrm{CaCl}_{2}$ pada hidrolisat protein limbah filet ikan patin menyebabkan terjadinya penurunan puncak absorbansi (Gambar 5). Penurunan puncak serapan pada hidrolisat protein dengan penambahan kalsium mengindikasikan adanya pengikatan kalsium oleh hidrolisat protein (Nie et al. 2014). Perubahan transisi absorpsi setelah dilakukan penambahan kalsium pada hidrolisat protein mencerminkan adanya penyesuaian elektron valensi akibat reaksi pengikatan kalsium oleh peptida (Jin et al. 2011). Nie et al. (2014) menyatakan bahwa penyerapan optimal pada hidrolisat protein sisik ikan terjadi antara panjang gelombang 200-280 nm yang merupakan karakteristik spektral dari peptida asam amino. Selain itu intensitas serapan kompleks kalsium peptida sisik ikan nila dengan penambahan kalsium lebih rendah bila dibandingkan dengan intensitas serapan untuk peptida saja, hal tersebut menunjukkan bahwa kalsium mengalampengikatan oleh hidrolisat protein sisik ikan nila.

\section{Komposisi Asam Amino Hidrolisat Protein Limbah filet Ikan Patin}

Hasil analisis komposisi asam amino produk hidrolisat protein limbah filet ikan patin dengan metode HPLC disajikan pada Tabel 1. Hidrolisat protein limbah filet ikan patin memiliki 15 macam asam amino (Tabel 1). Mutu protein menurut Purbasari (2008) dapat dinilai dari perbandingan asam amino yang terkandung dalam protein tersebut. Kualitas protein dapat dilihat dari kandungan 


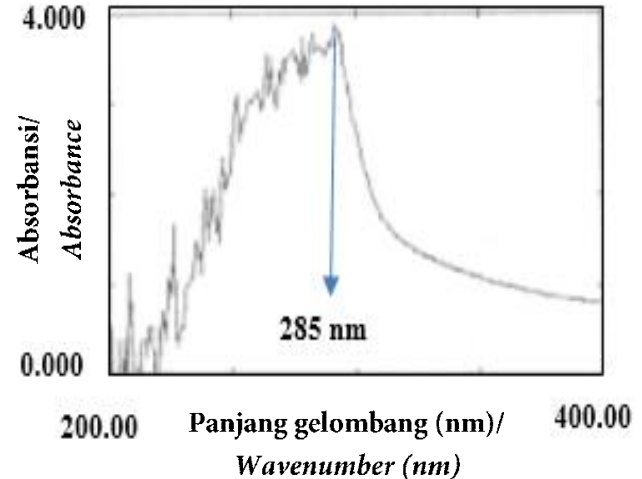

(a)

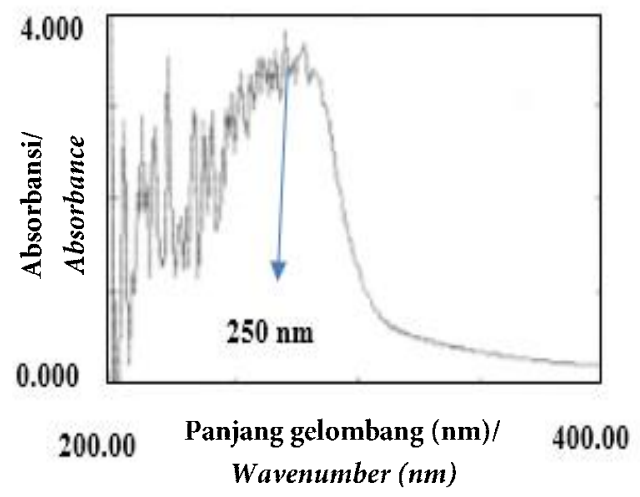

(b)

Gambar 2 (a) Puncak absorbansi pada hidrolisat protein, (b) Puncak absorbansi hidrolisat protein dan penambahan $\mathrm{CaCl}$

Figure 2 (a) Absorbance peak of protein hydrolyzate, (b) Absorbance peak of protein hydrolyzate and the addition of $\mathrm{CaCl}$

Tabel 1 Komposisi asam amino hidrolisat protein limbah filet ikan patin Table 1 Composition amino acid of hydrolyzate protein from Pangasius fillet waste

\begin{tabular}{|c|c|c|c|}
\hline $\begin{array}{l}\text { Asam amino/ } \\
\text { Amino acid }\end{array}$ & $\begin{array}{l}\text { Hidrolisat protein kepala } \\
\text { dan tulang ikan patin (\%)/ } \\
\text { Hydrolyzate of head protein } \\
\text { and patin (Pangasius) bones }\end{array}$ & $\begin{array}{c}\text { Hidrolisat protein tulang } \\
\text { ikan patin }(\%)^{\star} / \text { Hidrolyzate } \\
\text { protein patin (Pangasius) } \\
\text { bones }(\%)^{*}\end{array}$ & $\mathrm{EAA}^{* *}$ \\
\hline Alanina & $2.30 \pm 2.29$ & 2.35 & - \\
\hline Arginina & $1.55 \pm 0.47$ & 1.4 & - \\
\hline Asam aspartat & $3.27 \pm 1.05$ & 1.85 & - \\
\hline Asam glutamat & $6.27 \pm 2.13$ & 3.5 & - \\
\hline Fenilalanina & $2.03 \pm 0.46$ & 0.81 & - \\
\hline Glisina & $4.04 \pm 1.38$ & 1.75 & - \\
\hline Histidina & $0.49 \pm 0.09$ & 0.44 & 1.6 \\
\hline Isoleusina & $1.84 \pm 0.49$ & 0.58 & 1.3 \\
\hline Leusina & $2.72 \pm 1.67$ & 1.4 & 1.9 \\
\hline Lisina & $2.30 \pm 1.08$ & 4.8 & 1.6 \\
\hline Metionina & $0.75 \pm 0.13$ & 1.25 & 1.7 \\
\hline Serina & $1.21 \pm 0.34$ & 1.4 & - \\
\hline Tirosina & $0.84 \pm 0.22$ & 1.15 & - \\
\hline Treonima & $1.05 \pm 0.33$ & 1.2 & 0.9 \\
\hline Valina & $1.95 \pm 0,60$ & 0.87 & 1.3 \\
\hline Total asam amino & 32.68 & 25.65 & \\
\hline
\end{tabular}

${ }^{\star}$ Amiza et al. (2013)

** asam amino esensial yang disarankan untuk orang dewasa (FAO/WHO 1990)

asam amino penyusunnya (Sinlae et al. 2015). Suatu protein yang dapat menyediakan asam amino esensial dalam suatu komposisi yang hampir menyamai kebutuhan manusia, mempunyai mutu yang tinggi.
Produk hidrolisat protein limbah filet ikan patin mengandung 8 asam amino esensial yaitu histidina, treonina, metionina, valina, fenilalanina, isoleusina, leusina dan lisina serta 7 asam amino nonesensial yaitu 
asam aspartat, asam glutamat, serina, glisina, arginina, alanina, dan tirosina. Asam amino yang memiliki kandungan tertinggi adalah asam glutamat yaitu sebesar 6,27\%. Asam amino yang memiliki kandungan terendah yaitu histidina sebesar $0,49 \%$. Total asam amino pada hidrolisat protein limbah filet ikan patin yaitu sebesar 52,68\%. Total asam amino pada hidrolisat protein limbah filet ikan patin lebih tinggi apabila dibandingkan dengan total asam amino hidrolisat protein tulang ikan patin pada penelitian Amiza et al. (2013).

Asam amino esensial pada hidrolisat protein tulang ikan patin umumnya lebih tinggi (kecuali untuk histidin dan leusin) dibandingkan dengan pola yang disarankan untuk manusia dewasa oleh FAO/WHO. Hal tersebut membuktikan bahwa komposisi asama amino pada hidrolisat protein limbah filet ikan patin memenuhi persyaratan standar tersebut sehingga dapat disarankan sebagai sumber nutrisi asam amino esensial yang baik sebagai bahan makanan. Charoenphun et al. (2013) menjelaskan bahwa kapasitas pengikatan kalsium oleh peptida dipengaruhi oleh kandungan asam amino penyusun protein.

Kroll (1984) menjelaskan bahwa aktivitas pengikatan kalsium diidentifikasi sebagai asosiasi rantai karboksil dari asam aspartat dan asam glutamat dengan kelompok imidazol dari histidin. Nie et al. (2014) juga menjelaskan bahwa pengikatan kalsium oleh hidrolisat protein ikan nila dikarenakan kalsium yang terkordinasi dengan gugus karboksi dari asam glutamat dan karbonil oksigen dari ikatan peptida. Bao et al. (2008) juga menjelaskan bahwa asam glutamat pada hidrolisat protein kedelai mempunyai peranan yang penting dalam kapasitas pengikatan kalsium. Gifford et al. (2007) menyatakan ligan $\mathrm{Ca}^{2+}$ umumnya disediakan oleh rantai samping dua asam amino yaitu asam aspartat dan asam glutamat.

\section{KESIMPULAN}

Hidrolisat protein ikan dari limbah filet ikan patin mempunyai aktivitas pengikatan kalsium. Aktivitas kalisum tertinggi terdapat pada hidrolisa dengan konsentrasi $6 \%$.

\section{DAFTAR PUSTAKA}

Amiza MA, Kong YL, Faazaz AL. 2012. Effect of hydrolysis on physicochemical properties of cobia (Rachycentron canadum) frame hydrolysate. International Food Research Journal. 19(1): 199-206.

Amiza MA, Ow YW, Faazaz AL. 2013. Physicochemical properties of silver catfish (Pangasius sp.) frame hydrolysate. International Food Research Journal. 20(3): 1255-1262.

[AOAC] Association of Official Analytical Chemist. 2005. Official Method of Analysis of the Association of Official Analytical Chemist. Arlington: The Association of Official Analytical Chemist Inc.

Bao XL, Lv Y, Yang BC, Ren CG, Guo ST. 2008. A study of the soluble complexes formed during calcium-binding by soybean protein hydrolysates. Journal of Food Science. 73(3): 117-122.

Chalamaiah M, Kumar B D, Hemalatha R, Jyothirmayi T. 2012. Fish protein hydrolysates: Proximate composition, amino acid composition, antioxidant activities and applications: A review. Food Chemistry (Birch ed.) 135(4): 3020-3038.

Charoenphun N, Benjamas C, Nualpun S, Wirote Y. 2013. Calcium-binding peptides derived from tilapia (Oreochromis niloticus) protein hydrolysate. European Food Research and Technology. 236(1): 57-63.

Gifford JL, Walsh MP, Vogel HJ. 2007. Review Article : Structure and metal ion binding properties of the $\mathrm{Ca}^{2+}$ binding helixloop-helix EF-Hand motifs. Biochemical Journal. 405(2): 199-221.

Haslaniza H, Maskat MY, Wan AWM, Mamot S. 2010. The effect of enzyme concentration, temperature, and incubation time on nitrogen content and degree of hydrolysis of protein precipitate from cockle (Anadara granosa) meat waste water. International Food Research Journal. 17: 147-152.

Hastarini E, Dedi F, Irianto HE, Budijanto S. 2012. Karakteristik minyak ikan dari limbah pengolaham filet ikan patin siam dan patin jambal. AGRITECH. 32(4): 403-410. 
Hoa MX, Lam TB. 2008. Optimization of enzymatic hydrolysis of viscera of Pangasiidae to obtain calcium-binding protein hydrolysate. Vietnam Journal of Agriculture and Rural Development. 38: 124-132.

Hoyle NT, Merritt JH.1994. Quality of fish protein hydrolysatesfrom herring (Clupea harengus). Journal of food science. 59(1): 76-79.

Jin GY, Fu WW, Ma MH. 2011. Preparation and stucture characterization of soluble bone collagen peptide chelating calcium. African Journal of Biotechnology. 10(50): 10204-10211.

Jung WK, Kim SK. 2007. Calcium-binding peptide derived from pepsinolytic hydrolysates of hoki (Johnius belengerii) frame. European Food Research and Technology. 224: 763-767.

[KKP] Kementrian Kelautan dan Perikanan. 2013. Laporan tahunan direktorat produksi tahun 2013. www.kkp.go.id. (17 Agustus 2016).

[KKP] Kementrian Kelautan dan Perikanan. 2015. Volume produksi perikanan budidaya. www.kkp.go.id. (17 Agustus 2016).

Litaay M. 2005. Peranan nutrisi dalam siklus reproduksi abalone. Oseana. 1(3): 1-7.

Mardiyah S, Sartika RAD. 2014. Gangguan kepadatan tulang pada orang dewasa di aderah urban dan rural. Jurnal Kesehatan Masyarakat Nasional. 8(6): 272-279

Mendez AIR, Hernandez CF, Lalanne GM, Sanches HH, Ortiz GD, Martinez CJ. 2015. Production of calcium and iron binding peptides by probiotic strains of Bacillus subtilis, B. Clausii and B. Coagulans GBI-30. Revista Mexicana de Ingenierta Quimica. 14(1): 1-9.

Nie R, Liu Y, Liu Z. 2014. The calcium-binding activity of fish scale protein hydrolysates. Journal of Agricultural Chemistry and Enviromental. 3(1B): 11-15.
Nurhayati T, Nurjanah, Casti HS. 2013. Karakterisasi hidrolisat protein ikan lele dumbo (Clarias gariepinus). Jurnal Pengolahan Hasil Perikanan Indonesia. 16(3): 207-214.

Pigott GM, Tucker BW. 1990. Utility Fish Flesh Effectively While Maintaining Nutritional Qualities. Seafood Effects of Technology and Nutrition. New York (US). Marcel Decker Inc.

Purbasari D. 2008. Produksi dan Karakterisasi Hidrolisat Protein dari Kerang Mas Ngur (Atactodea striata). [Skripsi]. Bogor (ID) : Institut Pertanian Bogor.

Sathivel S, Witoon P, Casey CG, Joan MK, Steven L. 2012. FA composition of crude oil recovered from catfish viscera. JAOCS. 79(10): 989-992.

Schmid FX. 2001. Biological Macromolecules: UV-visible Spectrophotometry. www.els. net (21 September 2016).

Sharma S, Raghvendar S, Shashank R. 2011. A review: bioactive peptides. Bioautomation. 14(4): 223-250.

Sinlae RN, Suwiti NK, Suardana IW. 2015. Karakteristik protein dan asam amino daging sapi bali dan wagyu pada penyimpanan suhu dingin $4^{\circ} \mathrm{C}$. Buletin Veteriner Udayana. 7(2): 146-156.

Thuy CX, Lam TB, Commick K. 2015. Biochemichal and functional properties of fish potein isolate from Pangasius hypophthalmus byproduct as influenced by time and degree of hydrolisis. International Food Research Journal. 22(1): 337-343.

Utomo BSB, Suryaningrum TD, Hrianto HR. 2014. Optimization of enzymatic hydrolisis of protein hydrolisate processing from waste of catfish filet production. Squalen Bulletin of Marine And Fisheries Postharvest and Biotechnology. 9(3): 107-114. 